\title{
Memahami Peran Psikologi Pendidikan Bagi Pembelajaran
}

\author{
Junier Sakerebau \\ STT Yesyurun Arastamar Seriti-Luwu \\ sakarebaujunier@gmail.com
}

\begin{abstract}
Educational psychology as a science that examines the problems of the soul and psychological activity of a person in relation to education as an interaction is a discipline that is quite important in examining the problems that interfere with or support the psyche of students in the learning process, so that through understanding the mental state of students then the teacher can set and try to find a solution to the problem, so for this matter, it is fitting for a teacher to need to have comprehensive knowledge about the psychology of education so that learning can take place effectively and directed.
\end{abstract}

Keywords: psychology, education, learning

\begin{abstract}
Abstrak: Psikologi pendidikan sebagai ilmu yang meneliti masalah jiwa dan aktivitas psikologis seseorang dalam kaitannya dengan pendidikan sebagai interaksi adalah disiplin yang cukup penting dalam memeriksa masalah yang mengganggu atau mendukung jiwa siswa dalam proses pembelajaran, Sehingga dengan memahami keadaan mental siswa maka guru dapat mengatur dan berusaha mencari solusi atas masalah tersebut, sehingga untuk hal ini, sepatutnya seorang guru perlu memiliki pengetahuan yang komprehensif tentang psikologi pendidikan sehingga pembelajaran dapat berlangsung efektif dan terarah.
\end{abstract}

Kata-kata kunci: psikologi, pendidikan, pembelajaran

\section{A. Pendahuluan}

Tujuan dari pendidikan adalah adanya proses perubahan pada aspek kognitif, afektif dan psikomotorik seseorang atau kelompok dan usaha mendewasakan manusia melalui upaya pengajaran dan pelatihan. Pendidikan merupakan sebuah proses interaksi dan pelatihan antara dua orang atau lebih, antara guru dan peserta didik yang mana menghasilkan suatu perubahan sikap dan tingkah laku kearah yang lebih baik.

Masalah pendidikan adalah suatu masalah yang menyangkut kehidupan bersama, baik kehidupan di dalam keluarga maupun di dalam masyarakat, pendidikan itu merupakan suatu kegiatan yang sangat penting karena merupakan suatu kegiatan yang menentukan bagi kehidupan manusia dan kebudayaannya. ${ }^{1}$

Oleh karena pendidikan yang dilakukan oleh masyarakat sekarang ini, itulah yang akan menentukan kehidupan bangsa dimasa depan, sehingga sangatlah penting untuk memperhatikan masalah pendidikan secara cermat sehingga kelemahankelemahan yang ada dalam dunia pendidikan dapat diperbaiki agar kehidupan

${ }^{1}$ Judowibowo Poerwowidagolo, Pendidikan, Pembangunan Dan Masa Depan Bangsa (Jakarta: BPK Gunung Mulia, 1994), 2. 
masyarakat dapat menjadi lebih baik di masa yang akan datang, itulah sebabnya dalam hal ini peranan pendidikan sangat penting.

Salah satu faktor keberhasilan dalam pendidikan adalah guru, untuk itu maka seorang guru oleh karena itu maka para guru perlu memiliki pengetahuan dan pengalaman yang luas dan lengkap yang dapat dijadikan sebagai metode dan sarana dalam menjalankan tugasnya sebagai pengajar. Iris V. Cully menyatakan:

Para pendidik yang peka menyadari bahwa kumpulan pengetahuan dan pengalaman manusia bukanlah satu-satunya ramuan untuk mengasuh anak-anak. Dalam tugas mereka harus pula tercakup suatu pemahaman akan faktor-faktor dalam hubungan antar pribadi. Hasil-hasil penyelidikan psikologi menunjukkan bahwa pertumbuhan dan perkembangan mencakup keutuhan pribadi dalam keseluruhan lingkungannya. Guru-guru sekolah yang baik, selalu sadar akan faktor-faktor demikian yang bekerja dalam tugas mereka. ${ }^{2}$

Selain guru, dalam belajar setiap peserta didik dipengaruhi oleh banyak faktor, yang dapat digolongkan menjadi dua faktor yaitu faktor intern, yaitu faktor yang berasal dari dalam diri peserta didik itu sendiri dan faktor ekstern yaitu faktor yang berasal dari luar peserta didik yaitu dari orang tua, dari guru dan dari masyarakat. Faktor intern dibagi menjadi tiga yakni faktor jasmaniah, faktor psikologis dan faktor kelelahan.

Di dalam faktor psikologis sekurang-kurangnya ada tujuh faktor yang mempengaruhi belajar antara lain: intelegensi, perhatian, minat, bakat, motif, kematangan dan kesiapan. Dan faktor-faktor inilah yang harus diperhatikan oleh setiap pendidik agar dapat mengendalikan dan mengatur belajar agar dapat berlangsung efektif, terarah dan optimal. ${ }^{3}$

Guru yang baik adalah guru yang dapat mengerti dan memahami permasalahan atau kendala dari seorang peserta didik dan persoalan psikologi peserta didik. Guru yang dapat memahami persoalan peserta didiknya adalah guru yang tidak memaksakan keinginannya kepada peserta didik, yang mendengarkan keluhan dan problematika belajar dari peserta didik, dan yang juga tidak memaksakan tugas yang melampaui kemampuan peserta didik. ${ }^{4}$

Psikologi adalah sesuatu yang sangat esensial dalam "dunia" pendidikan, ini menjadi hal yang sangat esensial karena dalam menyambut era globalisasi, pendidikan sangat berperan penting dan menjadi salah satu faktor yang paling menentukkan kemajuan suatu bangsa. Jika suatu bangsa tidak maju pendidikannya maka pasti bangsa itu tidak dapat bersaing dengan bangsa yang lain, dan akan menjadi bangsa yang terbelakang. Untuk hal ini maka psikologi harus diterapkan dalam dunia pendidikan, agar pendidikan dapat berjalan efektif.

Psikologi adalah ilmu yang mengkaji manusia dari sudut karakteristik dan perilaku manusia. Psikologi berasal dari bahasa Yunani "Psyche" yang berarti jiwa, roh atau sukma, sedangkan "logy" atau "logos" berarti ilmu atau ilmu pengetahuan. Jadi psikologi berarti ilmu tentang jiwa atau ilmu yang mempelajari tentang karakteristik dan gejala yang dialami jiwa manusia. ${ }^{5}$ Jadi dalam hal ini psikologi sangat berperan penting dalam pendidikan karena psikologi sebagai ilmu pengetahuan adalah berupaya memahami keadaan peserta didik yang berbeda satu dengan yang lainnya. Di mana pengetahuan tentang psikologi amat penting bagi guru

2 Iris V. Cully, Dinamika Pendidikan Kristen (Jakarta: BPK Gunung Mulia, 2004), 1.

3 Slameto, Belajar dan Faktor-Faktor yang Mempengaruhinya (Jakarta: Rineka Cipta, 2003),

60.

${ }^{4}$ Stephen Tong, Arsitek jiwa (Surabaya: Momentum, 1995), 95.

5 Syaiful Sagala, Konsep dan Makna Pembelajaran (Bandung: Alfabeta, 2003), 116. 
agar dapat memahami proses dan tahapan-tahapan belajar bagi para peserta didiknya.

Manfaat dan kegunaan psikologi pendidikan juga membantu untuk memahami karakteristik peserta didik apakah termasuk anak yang lambat belajar atau yang cepat belajar, dengan mengetahui karakteristik ini guru dapat mendesain pendekatan belajar untuk anak didik yang berbeda-beda tersebut, sehingga pembelajaran dapat dilaksanakan secara optimal sesuai karakteristik peserta didik. ${ }^{6}$ Sumadi Suryabrata menyatakan bahwa:

Inti persoalan psikologi pendidikan terletak pada anak didik sebab pendidikan adalah perlakuan terhadap anak didik yang secara psikologis perlakuan tersebut harus selaras dengan keadaan anak didik, dengan demikian persoalan psikologi yang berperan dalam proses pendidikan anak dapat terjawab apabila pendidik dapat memberikan bantuan kepada peserta didik agar berkembang secara wajar melalui bimbingan dan konseling, pemberian bahan pelajaran yang berstruktur dan berkualitas. ${ }^{7}$

Oleh karena itu seorang guru perlu terus menerus berusaha untuk memahami mereka yang akan dipimpinnya dalam proses pendidikan, para guru perlu mempelajari sifat-sifat dasar peserta didik yang diwarisi dari orang tua, pertumbuhan peserta didik. Dan para guru juga harus mempersiapkan dasar-dasar psikologi apa yang akan digunakan dalam pembentukan karakter peserta didik. Seorang guru perlu mengetahui mengapa seorang peserta didik melakukan sesuatu hal tertentu dan juga mengetahui pula kegiatan-kegiatan apa yang paling penting dan membantu dalam proses pendidikan. ${ }^{8}$

Sehingga merupakan sebuah keharusan bagi setiap pendidik yang bertanggung jawab bahwa dia dalam melaksanakan tugasnya harus berbuat dalam cara yang sesuai dengan keadaan peserta didik. Karena itu pengetahuan psikologi mengenai peserta didik dalam proses pendidikan adalah harus dijadikan kebutuhan pendidik untuk memiliki pengetahuan tentang keadaan jiwa peserta didik. ${ }^{9}$ Karena pendidikan hanya dapat berjalan efektif apabila pendidikan tersebut dapat menjawab dan memenuhi kebutuhan psikologi peserta didik.

\section{B. Psikologi Pendidikan Apa Itu?}

Psikologi ditinjau dari segi ilmu bahasa,berasal dari dua kata yunani yaitu psyche yang berarti jawa dan perkataan "logos"yang berarti ilmu atau ilmu pengetahuan.Jadi psikologi dapat berarti ilmu pengetahuan tentang jawa atau disingkat ilmu jiwa ${ }^{10}$,dan karena istilah" ilmu jiwa"masih kurang jelas pengertiannya maka psikologi masih diberikan definisi yang berdiri sendiri sebagai suatu disiplin ilmu pengetahuan yang disesuaikan dengan arah minat dan aliran-aliran pada saat itu,sehingga terkadang psikologi didefinisikan dalam hubungannya dengan disiplin ilmu biologi, sosiologi atau bahkan dengan disiplin ilmu filsafat.

Psikologi terus mengalami perkembangan dalam artinya. Ini disebabkan karena pengertian tentang jiwa tidak pernah ada kesepakatan sejak dahulu kala. ${ }^{11}$ Sifat dan sejarah psikologi dapat dibagi dalam tiga periode yaitu: (1) psikologi pra-

\footnotetext{
6 Ibid., 122.

${ }^{7}$ Sumadi Suryabrata,_Psikologi Pendidikan, (Jakarta: Raja Grafindo Persada, 2004).

8 Ibid., 2.

${ }^{9}$ Sarlito Wirawan Sarwono, Pengantar Umum Psikologi, (Jakarta: TNP, 1983), 60.

${ }^{10}$ Yanto Subiyanto dan Dedi Suryadi, Tanya-Jawab Pengantar Psikologi (Bandung, Armiko,

11 Sarlito Wirawan Sarwono, Psikologi Lingkungan (Jakarta: Gramedia, 1992), 16.
} 1980), 1. 
sistematik yang setua sejarah manusia dan terdiri dari renungan-renungan yang secara relatif tak tertata yang didasarkan kepada ide keagamaan dan mitologis. (2) psikologi sistematik yang berawal sekitar tahun 400 SM dimulai oleh Plato dan berisi renungan-renungan yang teratur secara rasional. (3) psikologi ilmiah yang bermula menjelang akhir abad ke-19 dan mengandung simpulan-simpulan yang factual yang bisa didefinisikan dan merupakan suatu satuan ilmu tersendiri.

Di zaman Yunani, para filsuf mencoba mempelajari jiwa. Plato seorang filsuf Yunani pertama yang mulai mendefinisikan tentang jiwa, bagi Plato apa yang tampak dalam dunia hanyalah bayangan dari sebuah dunia yang nyata,dan tak berubah dan ia menyebut dunia itu dengan idea atau jiwa.Ide atau jiwa menurut Plato adalah bersifat kekal, tidak berubah. ${ }^{12}$ Oleh Plato jiwa dan tubuh dipandang sebagai dua kenyataan yang harus dibedakan atau dipisahkan,jiwa berasal dari dunia ide yang mempunyai fungsi rasional, kehendak atau keberanian keinginan atau nafsu yang dihubungkan dengan pengendalian diri. Harun Hadiwijono menyatakan:

Jiwa adalah laksana subuah kereta yang bersais (fungsi rasional,)yang ditarik oleh kuda bersayap yaitu kuda kebenaran, yang lari keatas,ke dunia idea,dan kuda keinginan atau nafsu,yang lari kebawah,kedunia gejala tarik-menarik ahirnya nafsulah yang menang,sehigga kereta itu jatuh kedunia gejala dan dipenjarakan jiwa. ${ }^{13}$

Plato memandang jiwa sebagai suatu subtansi yang memberikan kehidupan dan pengetahuan yang sejati,yang dapat membuat orang dapat melihat dunia idea,dan mencari kebenaran yang sejati.

Pengertian Plato tentang jiwa yang adalah kekal ini mendapat perlawanan dari murudnya Aristoteles, Aristoteles mengemukakan kritik yang tajam atas pendapat Plato tentang ide-ide. ${ }^{14}$ Bagi Aristoteles jiwa bukanlah melainkan fungsi mengingat, sehingga psikologi bagi Aristoteles adalah ilmu yang mempelajari gejala-gejala kehidupan dan jiwa juga adalah unsur kehidupan. Aristoteles membagi jiwa dalam tiga macam yaitu ${ }^{15}$ :

1. Anima vegetative, yaitu Anima atau jiwa yang terdapat pada tumbuh-tumbuhan yang mempunyai kemampuan untuk makan,minum dan berkembang biak.

2. Anima sensitive, yaitu Anima atau jiwa yang terdapat pada kalangan hewan yang disamping mempunyai kemampuan seperti Anima vegetativa juga mempunyai kemampuan berpindah tempat,mempunyai nafsu dan dapat mengamati hal-hal yang terdapat pada Anima vegetativa.

3. Anima Intelectiva, yaitu jiwa yang terdapat pada manusia,selain mempunyai kemampuan-kemampuan seperti yang terdapat pada Anima sensitive juga memiliki kemampuan lain yaitu kemampuan berfikir dan berkemauan.

Pada abad ke-17, pengertian jiwa mengalami perkembangan lagi. Rene Descartes seorang filsuf Perancis (1596-1650) mencetuskan definisi bahwa psikologi adalah ilmu tentang kesadaran. ${ }^{16}$ Descartes mengatakan bahwa jiwa berhubungan dengan "roh-roh penting" dan melalui hubungan ini terjadi interaksi antara jiwa dan tubuh. Jiwa tidak dapat mempengaruhi roh-roh tersebut, namun dapat mengubah

\footnotetext{
12 Harun Hadiwijono, Sari Filsafat Barat 1 (Yogyakarta: Kansius, 1980), 40.

13 Ibid., 42.

14 Bertens, Ringkasan Sejarah Filsafat ( Yogyakarta: Kansius,1975), 14.

15 Yanto Subiyanto dan Dedi Suryadi, Tanya Jawab Pengantar Psikologi (Bandung: Armiko,1980), 1.

16 Sarlioto Wirawan Sarwono, Pengantar Ilmu Psikologi (Jakarta: Bukan Bintang, 1976), 3.
} 
arah gerak "roh-roh penting" tersebut. ${ }^{17}$ Bagi Aristoteles yang ada dalam manusia bukanlah tiga jiwa namun hanyalah satu yaitu jiwa rasional yang dimiliki manusia.

Dari Inggris seorang filsuf bernama George Berkeley (1685-1753) mendefinisikan jiwa sebagai persepsi. ${ }^{18}$ Menurut Berkeley jiwa dapat menjadi penyebab dari gagasan manusia. Berkeley cenderung menyetujui paham paham Descartes bahwa wujud (matter) bukan kenyataan jadi tidak riil, yang riil adalah hanya segala sesuatu yang ada dalam jiwa saja yaitu ide. Ide adalah sesuatu kenyataan yang mutlak yang tidak dapat dibantahb kebenarannya. Semboyan Berkeley yang terkenal adalah "Esse ist Percipe" (kebenaran adalah persepsi). Menurut Berkeley ide ada terlebih dahulu daripada penginderaan dan pengalaman dan perserpsi dipengaruhi ide, bukan oleh wujud yang efektif. ${ }^{19}$

Seorang filsuf pragmatis dari Amerika bernama William James menjadi orang pertama yang menulis buku tentang psikologi umum yang pertama, ia menekankan fungsi kesadaran, bukan komponen-komponen kesadaran perspektif ini dikenal sebagai fungsionalisme yang menekankan aplikasi praktis dalam riset sehari-hari, dan dari karya ini maka tonggak psikologi sebagai sebuah disiplin ilmu tersendiri mulai dipikirkan. ${ }^{20}$

Pada masa ini psikologi masih didefinisikan berdasarkan kepada kegunaannya, karena beragamnya pandangan ini maka dalam era yang lebih modern para ahli cenderung mencari titik temu. Pada tahun 1897 di Leipzig, Wilhelm Wundt untuk pertama kali mengajukan gagasan untuk memisahkan psikologi sebagai sebuah disiplin ilmu tersendiri. Objek studi dari psikologi Wundt lebih diarahkan bukan kepada konsep-konsep abstrak lagi melainkan lebih kepada tingkah laku yang bisa dipelajari secara objektif.

Wundt mendefinisikan psikologi sebagai ilmu yang menyelidiki pengalamanpengalaman yang timbul dari diri manusia, perasaan, pikiran dan motivasi dan bukan menyelidiki pengalaman yang timbul dari luar manusia karena pengalaman dari luar manusia adalah objek ilmu alam. ${ }^{21}$ Carole Wade dan Carrol Tavris menyatakan bahwa Psychology as the scientific study of behaviour and mental processes, and how they are affected by an organism's physical state, mental state an external environment."22

Dari pengertian secara etimologi dan dari beberapa ahli diatas maka penulis menyimpulkan bahwa psikologi adalah suatu ilmu yang menyelidiki serta mempelajari secara menyeluruh, kompeherensif dan kritis tentang sikap, tingkah laku dan aktivitas-aktivitas manusia, di mana sifat, tingkah laku dan aktivitasaktivitas tersebut merupakan manifestasi dari hidup kejiwaan.

\section{Kajian Psikologi Pendidikan}

Dalam kajian psikologi ini penulis akan memberikan batasan dan klarifikasi pengertian dasar psikologi dalam artikel ini. Dari etimologi yang telah dibahas penulis diatas, jelas bahwa psikologi menyangkut dengan persoalan jiwa dan aktivitas-aktivitas kejiwaan seseorang dalam hubungannya dengan pendidikan sebagai sebuah proses interaksi dalam pengembangan individu.

${ }^{17}$ Bertrand Russel, Sejarah Filsafat Barat (Yogyakarta: Pustaka Pelajar, 2002), 736.

18 Ibid., 738.

${ }^{19}$ Sarwono, Psikologi Lingkungan, 16.

${ }^{20}$ Paul D. Meier (Editor), Pengantar Psikologi Dan Konseling Kristen (Yogyakarta: Yayasan ANDI, 2004), 2.

21 Subiyanto, Tanya Jawab, 2.

${ }^{22}$ Carole Wade dan Carole Tavris, Psychology (New York: Harper \& Row Publishers, 1987), 4. 
Menurut buku pengantar psikologi ada 4 kajian psikologi yang berkaitan dengan pendidikan yaitu: ${ }^{23}$

\subsection{Kajian Biologis}

Pada dasarnya peristiwa psikologis berkaitan dengan aktivitas otak dan sistem saraf. Otak manusia memiliki lebih dari sepuluh miliar sel saraf dan jumlah interkoneksi yang hampir tidak terbatas. Pendekatan biologis untuk mempelajari manusia dan spesies lain berupaya mengkaitkan perilaku yang terlihat terhadap peristiwa listrik dan kimiawi yang terjadi di dalam tubuh.

Kajian biologis menghasilkan perkembangan dalam penelitian belajar dan memori. Pendekatan biologis dimaksudkan untuk mempelajari manusia dan spesies lain dengan mengaitkan perilaku yang terlihat terhadap peristiwa di dalam otak dan sistem saraf. Pendekatan ini mencoba menentukkan neurobiologis ${ }^{24}$ yang mendasari perilaku dan mental.

\subsection{Kajian Perilaku}

Dengan pendekatan perilaku dapat dipelajari seseorang melalui perilakunya dan bukan pada otak dan sistem sarafnya. Intropeksi terhadap perilaku memiliki kualitas tersendiri yang membedakannya dari observasi dalam bidang ilmu pengetahuan lain. Dengan mempelajari apa yang dilakukan oleh seseorang yaitu perilakunya maka ilmu psikologi yang objektif dapat dikembangkan.

Behaviorisme adalah sebutan yang ditujukan pada kajian psikologi tentang perilaku, yang di dalamnya memuat tentang peran stimulus-respon yang mempelajari stimulus-respon yang masih relevan di lingkungan, respon yang ditimbulkan oleh stimuli tersebut dan hadiah atau hukuman yang terjadi setelah respon tersebut.

Pendekatan perilaku tidak memutuskan perkembangan mental seseorang tanpa mempertimbangkan antara stimulus dan respon. Melalui stimulus-respon tersebut kajian perilaku dapat mengambil suatu kesimpulan yang objektif mengenai aktivitas mental seseorang.

\subsection{Kajian Kognitif}

Kajian kognitif merupakan reaksi terhadap behaviorisme. Penelitian kajian kognitif ini didasarkan pada asumsi bahwa (1) hanya dengan mempelajari proses mental secara objektif maka manusia dapat memperoleh pemahaman sepenuhnya tentang apa yang dilakukan oleh seseorang. (2) menggunakan analogi antara pikiran dan dan komputer. Informasi yang masuk diproses dengan berbagai cara, dipilih, dibandingkan dan dikombinasikan dengan informasi yang lain.

Perspektif kognitif berkembang sebagai reaksi terhadap sempitnya pandangan stimulus-respon. Memahami tindakan manusia semata-mata dalam pengertian stimulus dan respon mungkin telah memadai untuk meneliti bentuk perilaku yang sederhana, tetapi pendekatan ini telah mengabaikan sangat banyak bidang penting fungsi manusia.

\subsection{Kajian Psikoanalitik.}

Konsep psikoanalitik tentang perilaku manusia dikembangkan oleh Sigmud Freud. Asumsi dasarnya adalah bahwa sebagian besar perilaku manusia berasal dari

${ }^{23}$ Lyndon Saputra (Editor), Pengantar Teologi (Batam: Interaksara, td), 22-29.

24 Perilaku neurobiology adalah perilaku yang dilatarbelakangi oleh proses atau peristiwa listrik dan kimiawi yang terjadi di dalam tubuh. 
proses bawah sadar. Dengan proses bawah sadar Freud meyakinkan bahwa ada rasa takut dan keinginan yang tidak disadari dalam diri seseorang yang sangat mempengaruhi perilakunya.

Kajian psikoanalitik melihat bahwa semua tindakan memiliki suatu penyebab tetapi penyebab itu lebih merupakan suatu motif bawah sadar ketimbang penalaran rasional yang menggerakkan perilaku manusia. Kajian psikoanalitik memberikan cara baru untuk memandang beberapa masalah dalam kejiwaan seseorang.

\section{Ruang Lingkup Psikologi Pendidikan}

Pendidikan pada hakikatnya adalah suatu proses tanpa henti sejak manusia lahir hingga manusia mati. Dalam pendidikan terangkum semua aspek-aspek kehidupan yang membentuk kehidupan manusia, aspek biologis yang berkaitan dengan aktivitas otak dan system saraf, aspek fisik yang berkaitan dengan perkembangan fisik, aspek kognitif yang melihat dan memahami tindakan manusia semata dalam kerangka pengertian stimulus dan juga aspek kejiwaan yang merupakan perpaduan antara kognitif, kesadaran, persepsi serta gagasan.

Semua aspek ini saling berkaitan satu sama lain dan tidak bisa dipisahkan dalam pendidikan. Hakikat pendidikan yang adalah interaksi antara pengajar dan peserta didik dapat berjalan secara efektif apabila masing-masing individu dapat memahami karakteristik dan keadaan jiwa masing-masing. Kajian sistematis tentang proses-proses dan faktor-faktor yang berhubungan dengan pemahaman karakteristik dan keadaan jiwa tiap-tiap individu dalam dunia pendidikan disebut psikologi pendidikan. ${ }^{25}$ Lebih lanjut Witherington menyatakan:

Psikologi pendidikan tidak hanya dianggap sebagai suatu psikologi yang dipraktekkan saja. Psikologi pendidikan adalah suatu studi atau suatu ilmu pengetahuan yang mempunyai hak hidup sendiri, memang benar, bahwa aspek-aspek tertentu dari psikologi pendidikan nyata-nyata bersifat kefilsafatan tetapi sebagai suatu ilmu pengetahuan psikologi pendidikan telah memiliki susunan dan prinsip atau kebenaran dasar sendiri, fakta-fakta yang bersifat obyektif dan teknik yang berguna untuk penyelididkan. ${ }^{26}$

Seperti dalam ilmu-ilmu yang lain, jenis persoalan yang dihadapi oleh psikologi pendidikan sebagai ilmu pengetahuan juga memiliki keunikan dan kerumitan tersendiri karena disebabkan olah begitu luasnya persoalan dan juga karena adanya penyelidikan yang terus-menerus terhadap persoalan psikologi pendidikan oleh karena itu maka penulis merasa perlu membahas ruang lingkup psikologi pendidikan agar pembahasan dalam karya tulis ini lebih terarah dan terfokus.

\subsection{Pertumbuhan dan Perkembangan Individu}

Sejak manusia lahir maka kehidupan mulai ada dan akan mengalami pertumbuhan dan oerkembangan. Setiap manusia pasti akan mengalami hal ini. Hal ini tidak dapat dipungkiri lagi karena di dalam tubuh manusia dengan sendirinya akan terjadi perubahan baik itu perubahan fisik maupun jasmaniah.

Menurut C.P Chalvin seperti dikutip Desmita pertumbuhan adalah suatu pertambahan atau kenaikan dalam ukuran dari bagian-bagian tubuh atau dari

25 Witherington, Psikologi Pendidikan (Jakarta: Rineka Cipta, 1991), 12.

26 Ibid., 13. 
organisme sebagai suatu keseluruhan. ${ }^{27}$ Ini berarti bahwa pertumbuhan sebenarnya adalah berkaitan denga proses perubahan yang terjadi pada seluruh kehidupan fisik.

Di dalam proses pertumbuhan terjadi pula proses perkembangan. Hal ini tidak dapat dipisahkan karena pertumbuhan dan perkembangan adalah suatu hal yang menyangkut perubahan. Jika pertumbuhan adalah proses perubahan pada aspek fisik manusia dan terjadi secara spontanitas maka perkembangan seseorang itu terjadi karena aanya usaha belajar dank arena penyesuaian psikologi yang dilakukan oleh seseorang. Perkembangan adalah sesuatu yang mutlak dan tidak dapat terjadi kembali.

Perkembangan itu terjadi secara bertahap dan bersifat mutlak atau harus terjadi. Oleh karena itu pertumbuhan dan perkembangan pada umumnya terjadi dalam diri individu akan terus berlanjut tanpa henti hingga di akhir hayat.

Perkembangan secara luas menunjuk pada keseluruhan proses perubahan dari potensi yang dimiliki individu dan tampil dalam kualitas kemampuan, sifat dan ciri-ciri yang yang baru. Dalam istilah perkembangan juga tercakup konsep usia yang diawali dari saat pembuahan dan berakhir dengan kematian. ${ }^{28}$ Perkembangan secara umum meliputi perubahan kualitas dalam diri manusia dan bukan pada kuantitas atau penambahan fisik saja. Desmita menyatakan:

Perkembangan menghasilkan bentuk dan ciri-ciri kemampuan baru yang berlangsung dari tahap aktivitas yang sederhana ke tahap yang lebih tinggi. Perkembangan itu bergerak secara berangsur-angsur tetapi pasti, melalui suatu bentuk ke tahap bentuk yang lain, yang kian hari bertambah maju, mulai dari pembuahan dan berakhir dengan kematian. ${ }^{29}$

Pertumbuhan dan perkembangan pada umumnya sangat berpengaruh dalam dunia pendidikan karena dalam dunia pendidikan melalui pertumbuhan dan perkembangan dapat diketahui perubahan-perubahan mental, fisik dan rohani peserta didik dalam mengikuti pendidikan.

\subsubsection{Kejiwaan Anak}

Ruang lingkup kedua yang dikaji oleh psikologi pendidikan adalah psikologi atau keadaan jiwa dari anak. Masa kanak-kanak adalah masa yang paling mendasar dan merupakan titik awal dari pertumbuhan dan perkembangan dalam seluruh aspek dan fungsi yang ada dalam diri seseorang, ini menjadikan masa ini menjadi masa yang begitu penting sekaligus sulit.

Penting dalam arti bahwa pada masa ini apa yang dialami oleh seseorang akan sangat memberikan makna yang sangat mendalam dan begitu mempengaruhi pembentukan kepribadian seseorang dalam kehidupannya nanti di masyarakat, dan juga merupakan masa yang sulit karena pada masa ini terjadi kesulitan untuk membentuk kepribadian anak.

Psikologi pada masa kanak-kanak sangat dipengaruhi oleh keadaan lingkungan di mana dia berada, oleh karena itu perkembangan psikologi pada masa ini seharusnya terjadi secara teratur dan terarah menuju pada suatu tingkat kedewasaan dan peningkatan pada proses belajar.

Perkembangan psikologi peserta didik ada empat tahap yaitu, tahap sensorikmotorik, di mana seorang individu melakukan suatu gerakan refleks yang berulang kali untuk mencapai tujuan tertentu. Tahap pra-operasional, yaitu tahap di mana

${ }^{27}$ Desmita, Psikologi Perkembangan (Bandung: Remaja Rosda Karya, 2005), 5.

${ }^{28}$ Reni Akbar Hawari, Psikologi Perkembangan Anak (Jakarta: Grasindo, 2001).

${ }^{29}$ Desmita, Psikologi Perkembangan, 5. 
individu mulai menggunakan symbol dan membedakan antara simbol dan benda. Tahap konkrit operasional, yaitu tahap di mana individu mulai memakai hubungan timbal-balik. Tahap formal-operasional yaitu tahap di mana individu mampu berpikir secara abstrak dan hipotesis.

Tanpa orang lain yang membantu perkembangan anak maka anak akan mengalami gangguan pada jiwanya nanti sekalipun mungkin anak masih dapat memperkembangkan sesuatu dari dirinya sendiri tanpa bantuan dari luar, dengan tubuhnya yang kecil menjadi tubuh yang tinggi besar. Namun suatu hal yang pasti anak yang berkembang tanpa bantuan dari luar diri anak tersebut akan kehilangan hakikat kemanusiaannya dan akan mengalami ketidakseimbangan. ${ }^{30}$

Orang tua perlu mencari benang merah dan sinkronisasi beberapa hal yang utama, yang membantu anak mengembangkan hal-hal dasar dalam kepribadiannya. Sebagaimana orang tua memilih sekolah yang sesuai dengan orientasi nilai dan harapan mereka, begitu juga orang tua seyogyanya mengadaptasikan pola-pola pendidikan yang konstruktif dan positif dari sekolah. Paling tidak, di antara keduanya, saling mengisi - dan bukan saling meniadakan. Untuk itu lah, komunikasi orang tua dengan anak, dan komunikasi antara orang tua dengan pihak sekolah, menjadi hal yang sangat penting untuk dilakukan. Kita tidak bisa bersikap "tahu beres" baik terhadap anak maupunn pihak sekolah. Karena, ketika terjadi ketidakberesan, kita tidak bisa semata-mata menunjuk pihak sekolah sebagai penyebab masalah dari persoalan yang dihadapi anak. Bisa saja persoalan dimulai / terjadi di sekolah, namun kita harus melihatnya secara bijaksana, karena reaksi seorang anak terhadap sesuatu, sangat dipengaruhi oleh proses belajar yang dilaluinya dan pola asuh yang paling mendominasi bentukan sikap dan kepribadiannya.

Jadi, keluarga, adalah tempat utama pendidikan dan pengembangan seorang anak. Sekolah, pada dasarnya mengarahkan, memberikan bimbingan dan kerangka bagi anak untuk belajar, bertumbuh dan berkembang. Sementara keluarga, justru menjadi pusat pendidikan (center of education) yang utama, pertama dan mendasar.

Dalam masa perkembangan kejiwaan seorang anak membutuhkan pertolongan dan bantuan orang lain dan yang paling berperan adalah kedua orang tuanya. Orang tuanyalah yang bertanggung jawab penuh dalam perkembangan psikologi dan eksistensi anaknya. Dan tidak menutup kemungkinan peranan pendidik dalam pembentukan psikologi anak sehingga seorang pendidik haruslah dapat mengerti tahapan-tahapan tersebut sehingga melaluinya seorang pendidik dapat memberikan pemaknaan dalam proses pembelajaran sehingga seorang anak dapat memiliki kepribadian yang harmonis dalam perkembangannya.

Anak dalam hubungannya dengan diri sendiri dapat dikatakan merupakan suatu ciptaan yang khas. Perkembangan yang lancar dan teratur serta dengan mendapatkan bantuan yang baik dari luar diri anak tersebut baik itu dari orang tua maupun pendidik dapat menjadikan anak tersebut menjadi individu yang bertanggung jawab atas perbuatannya. ${ }^{31}$

\subsubsection{Kecerdasan (Intelegensi)}

Setiap manusia memiliki kecerdasan atau intelegensi yang berbeda-beda yang dibawa sejak lahir yang disebabkan oleh mental, budaya dan faktor gen. Sebab itu

30 Singgih D. Gunarsa, Psikologi Perkembangan (Jakarta: BPK Gunung Mulia, 2003), 5.

${ }^{31}$ Singgih D. Gunarsa, Psikologi Anak Bermasalah (Jakarta: BPK Gunung Mulia, 1995), 112. 
dalam psikologi pendidikan persoalan mengenai perbedaan intelegensi ini dianggap merupakan suatu ruang lingkup yang perlu dipelajari.

Cara seorang anak belajar adalah melalui bermain, ketika ia bermain maka anak akan menemukan sesuatu yang baru dan akan menimbulkan rasa keingintahuannya. Dan rasa ingin tahunyalah yang mendorong ia untuk belajar. ${ }^{32}$

Seorang anak memiliki rasa keingin tahuan yang sangat besar terhadap hal yang dianggap baru dan menarik oleh sebab itu yang terpenting dalam proses pembelajarannya adalah kebebasan sepenuhnya kepada anak untuk pengekspresian dirinya demi peningkatan intelegensi yang dimilikinya.

Peningkatan intelegensi seorang anak sangat penting karena akan sangat membantu dalam meningkatkan keberhasilan atau gagalnya seorang peserta didik dalam mengikuti proses pendidikan. Meskipun demikian perlu diingat bahwa prestasi belajar peserta didik semata-mata ditentuksn oleh tingkat kemampuan intelektualnya.

Faktor-faktor seperti motivasi, sikap, kesehatan fisik, mental, kepribadian, dan ketekunan serta faktor-faktor yang lain turut mempengaruhi dalam peningkatan prestasi. ${ }^{33}$ Dan semua faktor tersebut mengarah kepada intelegensi sehingga membuat intelegensi menjadi bagian integral yang penting dalam pendidikan. William stern seperti dikutip Kartini Kartono menyatakan Intelegensi sebagai kemampuan pembawaan yang dipergunakan untuk menggunakan secara tepat segenap alat-alat bantu dan pikiran, guna menyesuaikan diri terhadap tuntutantuntutan baru. ${ }^{34}$

Kemampuan intelektual dapat dicapai dengan pengajaran dan pendidikan yang teratur. Pada dasarnya intelegensi sebenarnya adalah perbuatan pola pikir yang sangat baik yang diwujud nyatakan dalam suatu aktivitas yang efisien, yang dilakukan dalam suatu perbuatan yang cepat, mudah dan tepat. ${ }^{35}$

Intelegensi dapat juga disebut dengan efektivitas belajar yang melaluinya hasil dari pembelajaran dapat diterapkan dalam kehidupan. Psikologi pendidikan mempelajari juga bagaimana cara untuk meningkatkan keefektivan belajar dengan pengaruhnya terhadap perkembangan kejiwaan seseorang.

\subsection{Motivasi}

Setiap perbuatanyang dilakukan, termasuk perbuatan belajar disebabkan oleh sesuatu dorongan. Dorongan tersebut berasal dari dalam diri seseorang individu untuk mencapai suatu tujuan, dorongan ini disebut dengan motivasi.

Motivasi orang tergantung pada kekuatan motifnya. Motif yang dimaksud dalam uraian ini adalah kebutuhan, keinginan, dorongan atau gerak hati dalam diri individu (Hersey, Blanchard dan Johnson, 1996), dengan kata lain sesuatu yang menggerakkan seseorang untuk bertindak dengan cara tertentu, atau sekurangkurangnya mengembangkan tertentu (Hodgetts,1996). ${ }^{36}$

Dalam dunia psikologi, dorongan yang dirasakan seseorang untuk melakukan sesuatu disebut sebagai motivasi. Motivasi tersebut dapat berasal dari dalam maupun dari luar diri seseorang. Kartini Kartono menjelaskan beberapa teori motivasi: ${ }^{37}$

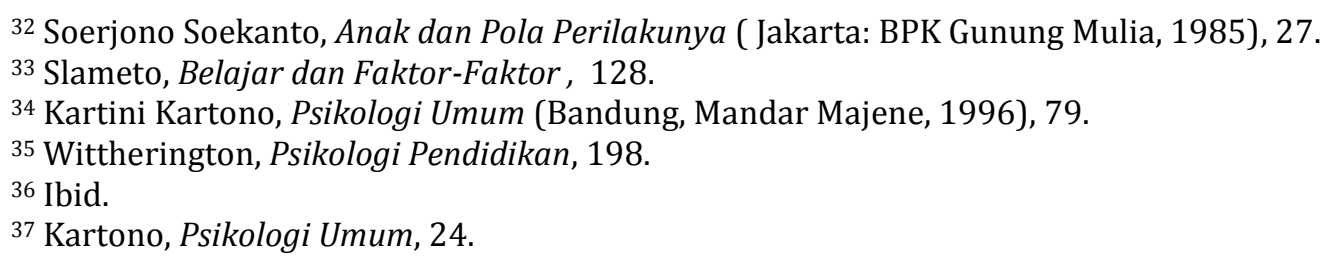




\subsubsection{Teori insentif}

Dalam teori insentif, seseorang berperilaku tertentu untuk mendapatkan sesuatu. Sesuatu ini disebut sebagai insentif dan adanya di luar diri orang tersebut. Contoh insentif yang paling umum dan paling dikenal oleh anak-anak misalnya jika anak, naik kelas akan dibelikan sepeda baru oleh orangtua, maka anak belajar dengan tekun untuk mendapatkan sepeda baru.

Insentif biasanya hal-hal yang menarik dan menyenangkan, sehingga anak tertarik mendapatkannya. Insentif, bisa juga sesuatu yang tidak menyenangkan, maka orang berperilaku tertentu untuk menghindar mendapatkan insentif yang tidak menyenangkan ini. Dapat juga terjadi sekaligus, orang berperilaku tertentu untuk mendapatkan insentif menyenangkan, dan menghindar dari insentif tidak menyenangkan.

\subsubsection{Pandangan Hedonistik}

Dalam pandangan hedonistik, seseorang didorong untuk berperilaku tertentu yang akan memberinya perasaan senang dan menghindari perasaan tidak menyenangkan. Contohnya: anak mau belajar karena ia tidak ingin ditinggal ibunya ke pasar/supermarket. Dari uraian di atas, dapat diasumsikan anak yang malas tidak merasa adanya insentif yang menarik bagi dirinya dan ia pun tidak merasakan perasaan menyenangkan dari belajar. Ada beberapa jenis motif motivasi pada diri seseorang yaitu: ${ }^{38}$

1. Motif motivasi internal: tenaga pendorong yang berasal dari dalam dirinya sendiri yang memotivasi orang tersebut untuk melakukan sesuatu perbuatan.

2. Motif motivasi eksternal: tenaga pendorong berasal dari luar diri orang tersebut, misalnya pendidik, orang tua, teman, buku-buku atau lain sebagainya yang mampu membangkitkan semangatnya untuk belajar.

3. Motif motivasi Intrinsik: tenaga pendorong yang sesuai atau berkaitan dengan perbuatan yang dilakukan. Teori motivasi intrinsik menjelaskan kesadaran tentang keingintahuan, memahami lingkungan, kesadaran eksistensi diri dan kesadaran tentang merealisasikan kemampuan. Teori ketidakcocokan kognitif menjelaskan ketegangan yang muncul pada saat manusia sadar adanya ketidakcocokan antara dua atau beberapa pengertian seperti persepsi-persepsi, sikap atau keyakinan. Teori motivasi keberhasilan ini menyelaraskan tentang pencapaian tujuan yang mengandung tiga faktor yaitu motif keberhasilan, kemungkinan keberhasilan dan nilai keberhasilan.

4. Motif motivasi ekstrinsik: tenaga pendorong yang berada di luar perbuatan atau tidak ada hubungan langsung dengan perbuatan yang dilakukannya tetapi menjadi penyerta. motivasi ekstrinsik dalam dunia pendidikan dapat dilakukan oleh pendidik. Pendidik harus mengambil keputusan tentang apa yang harus diajarkan, bagaimana menyajikan pelajaran dan bagaimana menentukan cara pengajaran agar peserta didik mengerti apa yang diajarkan dan mampu menerapkan dalam kehidupan nyata (Brohpy, 1990). Dorongan eksternal dari pendidik sangat penting bagi seseorang untuk mencapai keberhasilan belajar.

Motivasi memiliki peranan yang sangat besar di dalam upaya belajar, oleh karena tanpa dorongan atau motivasi seorang peserta didik tidak mungkin melakukan suatu kegiatan belajar dengan penuh antusias. Eysenck seperti dikutip Slameto menyatakan:

38 R. Ibrahim Nana Syaodih S, Perencanaan Pengajaran (Jakarta: Rineka Cipta, 1996), 28. 
Motivasi sebagai suatu proses yang menentukan tingkatan kegiatan, intensitas, konsistensi serta arah umum dan tingkah laku manusia, motivasi merupakan konsep yang rumit dan berkaitan dengan konsep lain seperti minat, konsep diri, sikap dan lainnya. ${ }^{39}$

Dengan pemahaman tersebut maka dapat dikemukakan aspek-aspek yang terkandung dalam motivasi keberhasilan sebagai berikut: (1) cenderung bertanggung jawab, (2) senang membahas kasus yang menantang, (3) menginginkan prestasi belajar yang lebih baik, (4) suka memecahkan masalah, (5) senang menerima umpan balik atas hasil karyannya, (6) senang berkompetisi untuk mencapai hasil belajar terbaik, (7) senang membahas kasus-kasus sulit, dan (8) melakukan segala sesuatu dengan cara yang lebih baik dibandingkan dengan temannya. ${ }^{40}$

Pernyataan ini berarti bahwa ada banyak fakta yang mempengaruhi motivasi belajar peserta didik, sehingga mengakibatkan terjadi tingkah-laku yang berbedabeda dari setiap peserta didik.

\section{Memahami Peran Psikologi Pendidikan}

Penyertaan pendidikan dalam usaha pembangunan di berbagai bidang jelas diperlukan. Stimulasi dan penyertaan upaya pendidikan pada masyarakat yang sedang membangun ternyata membuka hasil yang memuaskan di dalam mengatasi persoalan-persoalan baik itu persoalan di bidang politik, sosial, ekonomi maupun sosial budaya. ${ }^{41}$

Posisi pendidikan adalah posisi yang sentral dan dan universal yang mutlak ada dan harus diperhatikan secara khusus, karena ujung tombak akan setiap kebijakan keputusan yang akan diambil suatu pribadi atau instansi akhirnya harus ditentukan kembali kepada tingkat tinggi rendahnya pengetahuan yang telah diperoleh seseorang, dan juga kepada para pendidik di mana para pendidik dituntut unutk memberikan perhatian sebesar-besarnya bagi mutu pendidikan. Khoron Rosyadi menyatakan:

Dengan demikian ada hubungan fungsional antara dunia pendidikan dengan kebutuhan pembangunan, dan hal ini merupakan hubungan kemesraan antara dunia pendidikan dengan pembangunan di mana keduanya saling mengisi. Dalam UUD 1945 dengan jelas dinyatakan bahwa keberhasilan kita membangun republik ini tergantung pada kualitas para pelaksana atau aktor-aktor yang membangun... di mana para pelakasana atau aktor pembangunan akan terlahir melalui proses pematangan yang cukup lama dari rahim dunia pendidikakan sebagai pabrik. ${ }^{42}$

Sehingga pendidikan haruslah mampu menerobos berbagai bidang atau sektor pembangunan bangsa, karenanya maka pendidikan haruslah mampu menjawab kebutuhan para peserta didik. Pendidikan harus berjalan efektif dan tepat guna dalam pengaplikasian materi pendidikan.

Pengajar hadir dalam kegiatan mengajar sebagai seorang ahli yang berkompeten, berotoritas dan menguasai seluk-beluk pengajaran serta menguasai pengetahuan kan kemampuan atau daya serap peserta didik, karena komunikasi yang terjadi dalam interaksi dengan peserta didik cenderung didominasi oleh pola komunikasi satu arah karena pendidik tidak memiliki pengetahuan akan kemampuan

${ }^{39}$ Slameto, Belajar dan Faktor-Faktor, 170.

40 Ibid., 177.

41 Burhannudin Salam, Pengantar Pedagogik (Jakarta: Rineka Cipta, 1997), 172.

42 Khirodin Rosyadi, Pendidikan Profetik (Yogyakarta: Pustaka Pelajar, 2004), 2. 
dan daya serap peserta didik. ${ }^{43}$ Oleh karena itu maka pendidik harus dapat mengerti kemampuan peserta didik.

Pendidikan atau pengajaran yang baik harus senantiasa relevan dengan kebutuhan peserta didiknya. ${ }^{44}$ Dan agar pendidik dapat menjadi rekan belajar bagi peserta didik maka komunikasi, interaksi antara pengajar dan peserta didiknya haruslah berjalan flexible, bersifat pribadi serta tidak dibatasi oleh tembk-tembok ruangan kelas maka seorang pendidik setidaknya harus memiliki pengetahuan akan kepribadian peserta didiknya agar ia bisa memiliki pola pendekatan yang flexible, pribadi sehingga pelajaran yang ia berikan dapat menjadi flexible bagi peserta didik. ${ }^{45}$

Penguasaan prinsip kejiwaan peserta didik dalam hal belajar dapat menolong dan merangsang semangat peserta didik untuk belajar dengan lebih efisien dan lebih produktifitas lagi. ${ }^{46}$ Produktivitas dan efisiensi pembelajaran dapat dinilai berdasarkan kepada keseluruhan proses perencanaan, penataan dan pendayagunaan sumber daya untuk merealisasikan tujuan pendidikan secara efektif dan efisien. ${ }^{47}$ Dan dalam proses perencanaan, penataan serta pendayagunaan sumber daya tersebut seorang pendidik haruslah menciptakan proses atau suasana dan kegairahan belajar yang sesuai dengan keadaan psikis peserta didik.

Pengajar dituntut bukan hanya mentransferkan pelajaran kepada peserta didik, tetapi juga dituntut untuk melakukan tindakan dan cara hidup yang sesuai dengan apa yang diajarkan. ${ }^{48}$ Oleh karena itu seorang pendidik haruslah seorang yang telah mengerti tentangkepribadiannya sendiri sebagai seorang pengajar sebelum ia mengerti kepribadian peserta didiknya.

Para pendidik memandang psikologi sebagai sumber pengetahuan mengenai manusia agar dapat membuat praktek pendidikan dan hipotesis atau penunjuk dalam praktek-praktek pendidikan, dalam hubungan ini psikologi pendidikan dapat membantu tugas para pendidik untuk memilih metode belajar yang tepat agar pendidikan dapat berjalan secara efektif. ${ }^{49}$

Tugas seorang pendidik tidak hanya terletak pada penyiapan bahan pengajaran dan penyajiannya tetapi meliputi juga perencanaan dan pengarahan evaluasi belajar dan kegaiatan mengajar. ${ }^{50}$ Dan dalam perencanaan serta evaluasi ini maka diperlukan beberapa pendekatan agar pendidik mengukur kemajuan atau kegagalan peserta didik dan juga berusaha menilai segi-segi lain yang berkaitan dengan interaksi belajar-mengajar. Pendekatan tersebut harus didasarkan kepada pemahaman kan kepribadian peserta didik.

Dari uraian diatas maka penulis merumuskan bahwa tugas psikologi pendidikan dalam proses belajar-mengajar tidak hanya mencakup peningkatan mutu belajar peserta didik dalam kaitan dengan perkembangan psikisnya namun juga mempelajari perkembangan peserta didik dalam interaksinya dengan pelajaran dan faktor-faktor yang dapat mempengaruhi pembelajaran dalam pendekatanpendekatan yang dapat mempengaruhi pembelajaran.

\footnotetext{
${ }^{43}$ B. S. Sidjabat, Menjadi Pendidik Profesional (Bandung: Kalam Hidup, 1993), 7.

44 Ibid., 8.

45 Ibid., 8.

46 Mary Go Setiawan, Pembaruan Mengajar (Bandung: Kalam Hidup, td), 68.

47 Mulyasi, Menjadi Kepala Sekolah Profesional (Bandung: Remaja Rosda, 2003), 134.

48 Stephen Tong, Arsitek Jiwa II (Surabaya: Momentum, 2003), 8.

${ }^{49}$ Nana Sudjana, Teori-Teori Belajar Untuk Pengajaran (Jakarta: Universitas Indonesia, 1990).

50 Sidjabat, Menjadi Pendidik, 115.
}

4. 
Dalam buku Pembaruan Mengajar, Mary Go Setiawan menjelaskan beberapa peran psikologi pendidikan yang menyelidiki unsur kejiwaan cara belajar peserta didik.

\subsection{Membentuk Kepribadian Pendidik dan Prestasi Belajar}

Kepribadian pendidik memberikan pengaruh yang amat besar bagi sikap, karakter maupun hidup belajar dari seorang peserta didik, sehingga seorang pendidik sebelum mengajar maka ia perlu mengetahui kepribadiannya sendiri. Dan psikologi pendidikan sebagai sebuah disiplin ilmu yang mengkaji pengembangan semua potensi dan kecakapan yang dimiliki peserta didik dalam interaksi antar individu dapat membantu pendidik untuk mempunyai pemahaman yang baik tentang diri sendiri sehingga melalui pemahaman terhadap diri sendiri seseorang dapat mengajar secara bijaksana.

\subsection{Mengetahui Situasi}

Memadai atau tidaknya situasi dalam lingkungan belajar dapat berpengaruh bagi prestasi belajar, oleh karena itu psikologi pendidikan dapat menemukan permasalahan dari berbagai masalah pendidikan dengan melihat pada kepribadian peserta didik yang dipengaruhi situasinya.

\subsection{Emosi}

Mengetahui keadaan emosi seseorag sehingga dengan mengetahui emosi tersebut seorang pendidik dapat memahami dan memperlakukakan seorang peserta didik dengan bijaksana. Emosi adalah suatu keadaan jiwa yang dapat sangat berpengaruh bagi keadaan belajar peserta didik. Jika keadaan emosinya stabil maka ia dapat belajar dengan baik, begitu juga sebaliknya.

\subsection{Membangkitkan Motivasi belajar}

Tujuan psikologi pendidikan yang paling penting adalah membangkitkan motivasi belajar peserta didik. Psikologi pendidikan dengan pemahaman terhadap karakteristik jiwa peserta didik akhirnya haruslah mampu membangkitkan motivasi peserta didik untuk belajar.

Dari hal ini maka tujuan psikologi pendidikan merupakan alat bantu yang penting untuk dijadikan segala dasar untuk berpikir, bertindak bagi pendidik, konselor dan juga tenaga kerja professional kependidikan lainnya delam mengelola proses belajar-mengajar. ${ }^{51}$

Penulis menyimpulkan bahwa selain memahami karakteristik jiwa seorang peserta didik maka psikologi juga mempunyai tugas untuk menciptakan suasan belajar yang efektif, membantu pendidik untuk dapat memilih metode belajar yang paling efektif sesuai dengan karakteristik dan permasalahan peserta didik, membantu pendidik untuk dapat membangkitkan motivasi belajar peserta didik. Oleh karena itu maka psikologi pendidikan adalah sangat penting dalam pendidikan dan juga untuk pembangunan ke depan.

\section{Penutup}

Sebagai pendidik, sudah merupakan keharusan untuk bertanggung jawab dalam melaksanakan tugasnya, terlebih bagi pendidik atau guru agama Kristen,

\footnotetext{
${ }^{51}$ Syaiful Sagala, Konsep dan Makna Pembelajaran (Bandung: Alfabeta, 2003), 121.
} 
karena pendidikan agama tidak hanya sekedar mentransferkan pengetahuan secara kognitif pada peserta didik melainkan juga bagaimana pendidik tersebut mampu menerapkan dan menstimulir peserta didik untuk dapat mengaplikasikan pengetahuan yang didapat di dalam tindakan sehari-hari.

Oleh karena itu maka setiap pendidik harus dapat mengerti dan memahami keadaan jiwa setiap peserta didik agar melalui pemahaman tersebut, pendidik dapat mengukur kemampuan dan tingkat pemahaman peserta didik agar setiap pembelajaran yang berlangsung dapat berlangsung secara efektif. Hal ini didukung oleh Mukhtar Martins Yamin yang menyatakan bahwa "guru harus memenuhi ukuran kemampuan yang diperlukan untuk melaksanakan tugasnya, sehingga peserta didik dapat mencapai ukuran pendidikan yang tinggi". ${ }^{52}$ Hal ini berarti seorang pendidik agama Kristen harus dapat memiliki pengetahuan dan penguasaan yang memadai tentang keadaan psikologi peserta didik.

\section{Daftar Pustaka}

Bertens, K. Ringkasan Sejarah Filsafat. Yogyakarta: Kansius, 1975.

Cully, Iris V. Dinamika Pendidikan Kristen. Jakarta: BPK Gunung Mulia, 2004.

Desmita, Psikologi Perkembangan. Bandung: Remaja Rosda Karya, 2005.

Gunarsa Singgih D. Psikologi Anak Bermasalah. Jakarta: BPK Gunung Mulia, 1995.

Gunarsa, Singgih D. Psikologi Perkembangan. Jakarta: BPK Gunung Mulia, 2003.

Hadiwijono, Harun, Sari Filsafat Barat 1. Yogya: Kansius, 1980.

Kartini Kartono, Psikologi Umum. Bandung, Mandar Majene, 1996.

Meier. Paul D, (Editor), Pengantar Psikologi Dan Konseling Kristen. Yogyakarta: Yayasan ANDI, 2004.

Mulyasi, Menjadi Kepala Sekolah Profesional. Bandung: Remaja Rosdakarya, 2003.

Poerwowidagolo, Judowibowo. Pendidikan, Pembangunan Dan Masa Depan Bangsa, Jakarta: BPK Gunung Mulia, 1994.

R. Ibrahim Nana Syaodih S, Perencanaan Pengajaran. Jakarta: Rineka Cipta, 1996.

Reni Akbar Hawari, Psikologi Perkembangan Anak (Jakarta: Grasindo, 2001).

Rosyadi. Khirodin, Pendidikan Profetik. Yogyakarta: Pustaka Pelajar, 2004.

Russel, Bertrand, Sejarah Filsafat Barat. Yogyakarta: Pustaka Pelajar, 2002.

Sagala, Syaiful, Konsep Dan Makna Pembelajaran, Bandung: Alfabeta, 2003.

Salam. Burhannudin, Pengantar Pedagogik. Jakarta: Rineka Cipta, 1997.

Saputra, Lyndon (Editor), Pengantar Teologi. Batam: Interaksara, td.

Sarwono, Sarlito Wirawan, Pengantar Umum Psikologi, Jakarta: TNP, 1983.

Setiawan, Mary Go., Pembaruan Mengajar Bandung: Kalam Hidup, td.

Sidjabat. B. S, Menjadi Pendidik Profesional Bandung: Kalam Hidup, 1993.

Slameto, Belajar dan Faktor-Faktor Yang Mempengaruhinya. Jakarta: Rineka Cipta, 2003.

Soekanto, Soerjono. Anak dan Pola Perilakunya. Jakarta: BPK Gunung Mulia, 1985.

Subiyanto Yanto dan Surya, Dedi, Tanya-Jawab Pengantar Psikologi. Bandung: Armiko, 1980.

Sudjana, Nana, Teori-Teori Belajar Untuk Pengajaran. Jakarta: Universitas Indonesia, 1990. 2005), 84.

52 Mukhtar Martins Yamin, Metode Pembelajaran Yang Berhasil (Jakarta: Nimas Multimas, 
Suryabrata, Sumadi, Psikologi Pendidikan, Jakarta: Raja Grafindo Persada, 2004.

Tong, Stephen, Arsitek jiwa, Surabaya: Momentum, 1995.

Tong. Stephen Tong, Arsitek Jiwa II. Surabaya: Momentum, 2003.

Wade Carole dan Tavris Carole, Psychology. New York: Harper \& Row Publishers, 1987.

Witherington, Psikologi Pendidikan. Jakarta: Rineka Cipta, 1991.

Yamin, Mukhtar Martins, Metode Pembelajaran Yang Berhasil. Jakarta: Nimas Multimas, 2005. 